\title{
What Are the Molecules Involved in Regulatory T-Cells Induction by Dendritic Cells in Cancer?
}

\author{
Rodrigo Nalio Ramos, Cristiano Jacob de Moraes, \\ Bruna Zelante, and José Alexandre M. Barbuto \\ Department of Immunology, Institute of Biomedical Sciences, University of Sao Paulo, Avenida Professor Lineu Prestes, \\ 1730 Sao Paulo, SP, Brazil \\ Correspondence should be addressed to José Alexandre M. Barbuto; jbarbuto@icb.usp.br
}

Received 28 February 2013; Accepted 22 April 2013

Academic Editor: Beatrice Gaugler

Copyright (C) 2013 Rodrigo Nalio Ramos et al. This is an open access article distributed under the Creative Commons Attribution License, which permits unrestricted use, distribution, and reproduction in any medium, provided the original work is properly cited.

\begin{abstract}
Dendritic cells (DCs) are essential for the maintenance of homeostasis in the organism, and they do that by modulating lymphocyte priming, expansion, and response patterns according to signals they receive from the environment. The induction of suppressive lymphocytes by DCs is essential to hinder the development of autoimmune diseases but can be reverted against homeostasis when in the context of neoplasia. In this setting, the induction of suppressive or regulatory T cells contributes to the establishment of a state of tolerance towards the tumor, allowing it to grow unchecked by an otherwise functional immune system. Besides affecting its local environment, tumor also has been described as potent sources of anti-inflammatory/suppressive factors, which may act systemically, generating defects in the differentiation and maturation of immune cells, far beyond the immediate vicinity of the tumor mass. Cytokines, as IL-10 and TGF-beta, as well as cell surface molecules like PD-L1 and ICOS seem to be significantly involved in the redirection of DCs towards tolerance induction, and recent data suggest that tumor cells may, indeed, modulate distinct DCs subpopulations through the involvement of these molecules. It is to be expected that the identification of such molecules should provide molecular targets for more effective immunotherapeutic approaches to cancer.
\end{abstract}

\section{Background}

Regulatory T cells (Tregs) are crucial to the maintenance of tolerance to autoantigens [1]. The failure of Treg function or their depletion has been implicated in the development of many autoimmune diseases in humans and in mouse models [2]. However, Treg-mediated suppressive activity can also contribute to the immune escape of pathogens or tumors $[3,4]$. Nowadays, regulatory T cells (Tregs) are considered one of the major obstacles to the success of immunotherapeutic approaches to cancer [5-8]. Several studies have described the direct association between Treg increase and tumor development, implicating this phenomenon as one of the most important escape mechanisms in different tumor types $[7,9,10]$. Many evidences have demonstrated that Treg accumulation is not restricted to the tumor site but is observed in the peripheral blood as well, from patients with distinct malignant tumors, including pancreas and breast [11], lung [12], and ovarian cancer [4, 12]. Indeed, elimination of Tregs in mouse tumor models can improve antitumor immune responses and survival $[9,13]$.

Dendritic cells (DCs) are believed to act as sensors of the homeostatic equilibrium of their environment, where they capture antigens to present to T lymphocytes. Thus, depending on the status of the tissue, they might induce immunity or tolerance to the antigens they present. Indeed, many in vitro studies have demonstrated that DCs are essential for regulatory T-cells induction $[14,15]$, apparently depending on various distinct mechanisms [16], but also, frequently, on external sources of cytokines, among which TGF-beta seems to play a predominant role [17]. Not surprisingly, therefore, during tumor development the balancing role of DCs in the T helper versus Treg stimulation seems to be deeply modified $[8,18]$.

However, despite all the accumulated data, the precise role of DCs in the imbalance between $\mathrm{T}$ helper and Tregs 
in cancer is still unclear. Do the observed biases of DC function in tumor bearers reflect a previous disturbance in their immune homeostasis or are these deviations of DC function the cause of the other immunological abnormalities? How significant is the contribution of these DC deficits to the escape of tumors from the body's control? Though the answer to these questions is not available yet, the increasing knowledge and characterization of DC behavior in the presence of tumors allows us to predict that it will be, and, furthermore, that, once reached, it will provide us with powerful tools for the clinical management of cancer. With these goals in view, we discuss, here, the impact of tumor presence in the membrane phenotype and function of DCs and their bias to induce/expand regulatory $\mathrm{T}$ cells.

\section{The Tumor Microenvironment: A Tolerogenic Milieu}

Several studies have described the potential impact of tumorderived products in the suppression of immunity. Signals derived from tumors not only act directly upon immune effector cells but also induce the conversion and/or the recruitment of cells with suppressive functions to their microenvironment [19]. In consequence, tumors are typically characterized by the presence of higher concentrations of anti-inflammatory molecules, such as TGF-beta, IL-10, and prostaglandin E2 [20-23], increased amounts of angiogenic factors, as the vascular endothelial growth factor (VEGF) [24], and augmented CCL22 chemokine gradient [25] in addition to the local expression of immuneinhibitory molecules, including CTLA4 and PD-1/PD-L1 [26, 27]. Altogether, these constitute, nowadays, the most highly sought targets to achieve the breakdown of tumor-associated microenvironment-induced tolerance. Still, in order to obtain an immune recovery in face of tumors, we still need to identify the source of the tolerogenic signals. Though tumors cells may produce such mediators, also tumor-infiltrating leukocytes may be their source, and, indeed, the study of such populations has revealed that regulatory Foxp $3^{+} \mathrm{T}$ cells (Tregs) [28], anti-inflammatory M2-macrophages [29], plasmacytoid dendritic cells (pDCs) [30], and immature myeloid DCs [31] accumulate in human neoplastic tissues and patients' blood [4] and have been associated with poor prognosis for the patients specific cancer types.

As mentioned, the presence of tolerance-inducing conditions seems not to be restricted to the tumor microenvironment. Several studies have demonstrated the increase of anti-inflammatory cytokines and the higher frequency of suppressive cells in the bloodstream and lymph nodes from cancer patients. The detection of higher amounts of cytokines like TGF-beta [32], M-CSF [33], and IL-6 [34, 35] in patients' serum could suggest that the tumor presence affects cells in distant organs, thus resulting in systemic alterations which could allow tumors not only to grow locally unchecked but also to metastasize without an effective immune barrier. In agreement with that are: the higher frequency of myeloidderived suppressor cells (MDSCs) (a group of immature but potent suppressor cells capable of down-regulating anti-tumor immunity) found in cancer patients' circulation [36]; the decreased frequency of circulating and tumorinfiltrating myeloid DCs [37, 38]; and the CD4 lymphopenia observed in cancer patients [39-41]; all three important alterations of immune homeostasis in cancer patients that, consequently, hamper the effectiveness of their treatment.

\section{DCs: Targets to the Tumor Tolerogenic Milieu}

Dendritic cells (DCs) are the best adapted professional antigen-presenting cells (APCs) able to initiate, coordinate, and regulate the adaptive immune responses by inducing naive T-cells differentiation into diverse $\mathrm{T}$ helper lymphocyte subtypes [42-46]. Generally, at homeostasis condition, tissue-resting DCs are in immature status (lower MHC class II and costimulatory molecules expression) and strategically located to sense and acquire antigenic products from the environment. Using nonspecific receptors, immature DCs can recognize pathogens or danger-associated molecular patterns (as known, PAMPs and DAMPs, resp.) and migrate to lymphoid organs, at the same time as they increase their expression of MHC, CD80, CD86, and CD40 surface molecules and become ready to activate naïve $\mathrm{T}$ lymphocytes [44]. DCs are also crucial for the induction/maintenance of T-cell tolerance to antigens acquired in "healthy" tissues, thus performing an essential role in the prevention of autoimmunity [47].

It is also evident that the term DC is applied to several distinct subpopulations, classified, still incompletely, in relation to their tissue localization, migratory ability, surface markers' expression, and the profile of soluble factors they release. Though still uncertain, it is becoming increasingly clear that any classification of DCs will be insufficient to accommodate all the plasticity of these cells. Therefore, a better approach to the problem would be to describe, as well as possible, the DCs found in a certain condition, and from that, to correlate their phenotype in that specific situation with the known functions of these cells. This has been done in relation to DCs within tumors and has shown that tumors modify significantly the phenotype of DCs within their microenvironment $[8,22]$. Various observations point to a mainly functional deficit of these cells in immune stimulation, due to a decreased frequency of mature, functionally competent DCs within tumors [31] and in peripheral blood [48]. Actually, we have already shown an altered expression of CD86 in Mo-DCs from advanced cancer patients, which was, apparently, corrected by an immunotherapeutic approach [49]. Importantly, the presence of pDCs in tumor sites has been also related to poor prognosis in cancer patients [30], and their functional investigation revealed a considerable low to absent IFN-alpha production in breast and ovarian cancer $[50,51]$. The tumor-associated stroma and cancer cells per se can generate signals that drive DC to a tolerogenic pathway, characterized, mainly, by a poor upregulation of MHC class II and costimulatory molecules and absent or low production of proinflammatory cytokines [52], thus favoring tumor 


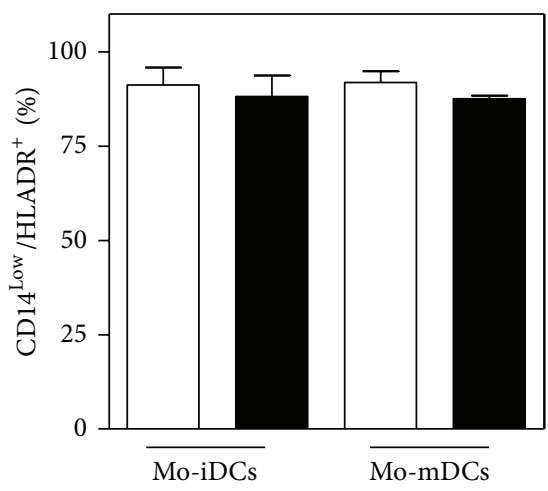

(a)
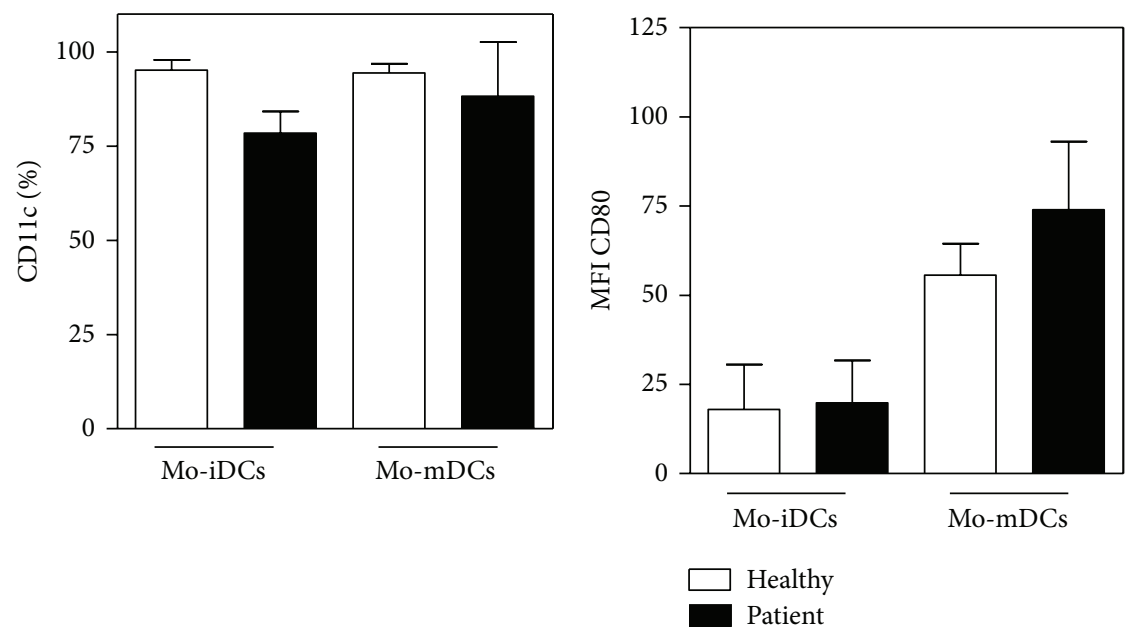

(c)

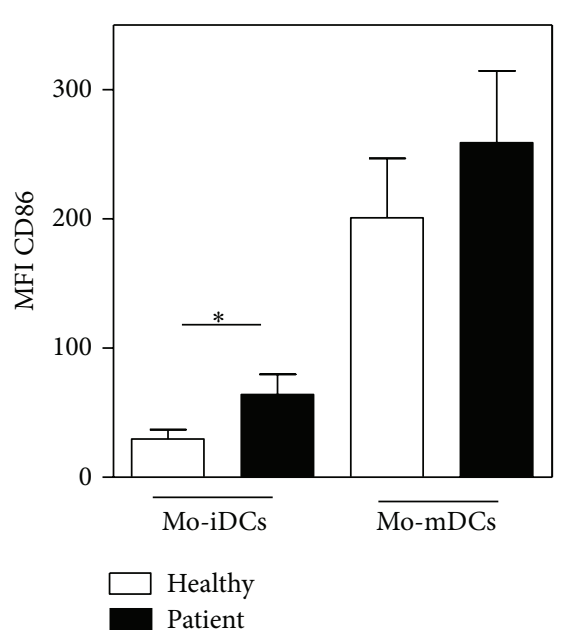

(d)

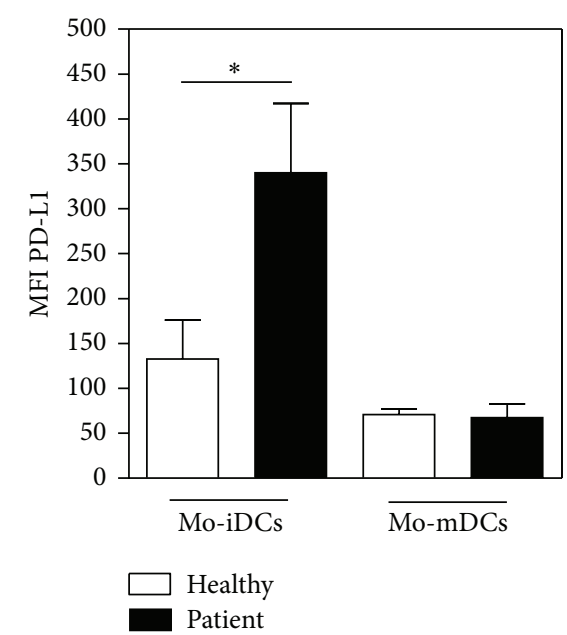

(e)

FIGURE 1: Patients' immature Mo-DCs express higher levels of PD-L1. Blood monocytes from control, and breast cancer patient subjects were cultured in the presence of IL-4 and GM-CSF for seven days and, subsequently, characterized. Flow cytometry analysis showing grouped frequency of CD14 ${ }^{\mathrm{Low}} / \mathrm{HLADR}^{+}$(a) and CD $11 \mathrm{c}^{+}$(b) cells and Mean Intensity Fluorescence (MFI) values of CD $14^{\mathrm{Low}} / \mathrm{HLADR}^{+}$gated cells to CD80 (c), CD86 (d), and PD-L1 (e) molecules in Mo-iDCs from healthy donors and breast cancer patients $\left({ }^{*} P<0.05\right.$, two-tailed unpaired $t$-test; healthy $n=5$; patients $n=9$ ). (Mature Mo-DCs were activated by TNF-alfa for 48 hours.)

evasion from the immune system. Interestingly, in tumorbearing mouse, the presence of DCs is also crucial for cancer vascularization, and when DCs are depleted, the elimination of malignant cells can be enhanced [53, 54]. Additionally, another elegant study showed that human myeloid DCs expressing OX40L stimulate Th2 immunity in vitro, under the influence of thymic stromal lymphopoietin (TSLP) derived from breast tumor cells [55]. Such findings may explain the bias towards a Th2 inflammatory tumor microenvironment found in breast cancer.

Since it became possible to achieve DC differentiation from human blood monocytes (Mo-DCs) [56], the immunostimulatory potential of these cells could be harnessed for cancer immunotherapy [57-60]. On the other hand, in vitro findings, describe that tumor cells present during human monocyte differentiation cause alteration in their molecular expression and unsuccessful DC differentiation, even under exogenous cytokine addition [61-63]. In addition, we have shown that breast cancer patients' monocyte-derived DCs are phenotypic altered and biased to induce Tregs [64], even though differentiated without the presence of tumor cells in the culture.

Immature Mo-DCs from patients express higher levels of CD86 and PD-L1 membrane molecules after 7 days in the presence of IL-4 and GM-CSF (Figure 1). Though the expression of CD86 could be interpreted as an enhanced costimulatory ability, the same cannot be implied for PDL1. PD-L1, also known as $\mathrm{B} 7-\mathrm{H} 1$, has been described as an inhibitory molecule in T lymphocyte activation $[65,66]$ and also related to $\mathrm{T}$ effector to Treg conversion [67] and the induction of T cell anergy by Mo-DCs [68]. Furthermore, its expression has been described as enhanced in monocytes from peritumoral stroma in hepatocellular carcinoma [26] and in lung cancer infiltrating DCs [69]. 


\section{Regulatory T-Cells Induction by Tumor-Affected DCs}

The induction and expansion of Tregs by DCs are generally related to their role in the maintenance of tolerance to self [16]. Several studies have been developed, trying to identify the signals that drive DCs into that function and, thus, eventually allow the use of such educated DCs to control unwanted immune responses, like those against transplanted tissues or in autoimmune diseases [70]. Actually, the acquisition of the ability to promote Tregs is an integral part of the physiologic function of DCs, as can be noted, for instance, in the presence of apoptotic cells $[71,72]$. In this search, anti-inflammatory cytokines as IL-10 [73, 74], TGF-beta [75], and vitamin D3 addition [76, 77] have been shown to affect mouse and human DCs, causing them to stimulate regulatory or suppressive T lymphocytes [78]. Intriguingly, even inflammatory cytokines, as TNF-alpha, have been associated with tolerogenic DC induction in autoimmune disorders like the murine Experimental Autoimmune Encephalomyelitis (EAE) [79]. Paradoxically, the same functional status of DCs, which is the still unreached aim of research in autoimmunity and transplantation studies, is the natural status of DCs in cancer, which is, again, beyond our powers of effective modulation. Tumor cells are associated with lower activation of immune cells and hinder APC activation [32, 80, 81] and, also can attract regulatory $\mathrm{T}$ cells to their microenvironment $[4,11,12]$, all phenomena which would be more than welcome in the aforementioned autoimmune and transplant recipients. Regarding APCs, in vitro studies showed Treg induction by human Mo-DCs stimulated by pancreatic or lung tumor cells $[61,62]$, the ability of human intratumoral pDCs, to expand Tregs ex vivo in breast cancer [50] and to induce suppressive activity by $\mathrm{T}$ cells in prostate cancer [82]. These findings show that tumor cells are able to promote Tregs induction by DCs in patients, and also to affect DCs from healthy donors, causing them to stimulate Tregs. Finally, our group has demonstrated that this effect of tumors upon DCs does not depend on the continuous presence of neoplastic cells, since Mo-DCs from breast cancer patients even when differentiated in vitro and, therefore, away from the direct tumor influence, are poor T-cell stimulators and biased to induce $\mathrm{CD} 4^{+} \mathrm{CD} 25^{+} \mathrm{Foxp}^{+}$regulatory $\mathrm{T}$ cells when cocultured with naïve $\mathrm{CD} 4^{+} \mathrm{CD} 45 \mathrm{RA}{ }^{+}$lymphocytes (Figure 2). It should be noted that this bias was present, regardless of the maturation stimulus used to activate the patients' Mo-DCs [64]. Taken together, these data indicate that during tumor development a systemic tolerogenic status of DCs is favored, enhancing their ability to expand/recruit Tregs and whose specific mechanisms are still largely undetermined.

\section{Potential Mechanisms of Tumor-Affected DCs in the Induction of Tregs}

Cytokines, as TGF-beta and IL-10 in addition to IL-2, are currently used to expand effectively murine and human Tregs in vitro. Interestingly, the same cytokines can also induce DCs to stimulate Tregs in vitro $[17,74,75]$. This may suggest that the major signals responsible for the generation and expansion of regulatory $\mathrm{T}$ cells in vitro and in vivo are already known. However, few data are available in regards to the mechanism of tumor-conditioned DCs in Tregs induction. Recent findings have demonstrated that infiltrating pDCs from ovarian [83] and breast tumor [84] can express high levels of ICOS-L, a phenomenon that could explain their ability to stimulate Foxp $3^{+}$Tregs in vitro. Our own data also have shown that the Tregs induction by Mo-DCs from cancer patients could be partially reversed by blocking of TGF-beta in vitro, and not by LPS, proinflammatory cocktail, or sCD40L activation [64]. TGF-beta is a multifunctional cytokine that regulates T-cell growth and development [85], inhibits IL-2 production, and has potent antiproliferative effects on $\mathrm{CD}^{+} \mathrm{T}$ cells [86], principally by inducing regulatory $\mathrm{T}$ cells [87]. However, since blocking of this cytokine was not enough to abolish the Treg-induction bias of the patients' Mo-DCs, it is likely that the TGF-beta signal may act together with other factors. Among the candidates for this cosignaling it is interesting to note that patients' MoDCs expressed higher levels of surface CD86 and PD-L1 (Figure 1), both molecules that have been also implicated in the balance of Tregs stimulation [88-91]. Thus, the TGF-beta signal may actuate together with surface molecules signals to "complement" the patients' Mo-DCs signalization in the induction/expansion of Tregs, as we showed here that DC-T cell contact is essential in that phenomenon (Figure 3).

\section{Concluding Remarks}

Tregs are recognized as central in the maintenance of tolerance to self [1] but may be also involved in the failure of the immune system to eliminate or control infections [3], tumors [13] and to respond to therapeutic vaccination [92]. Nowadays, it is also broadly accepted that DCs may play a crucial role in tolerance by the induction of Tregs at peripheral tissues and organs [16]. On the other hand, it is also known that tumor cells can alter profoundly the ability of DCs to instruct the immune system to generate adaptive antitumor responses [22], thus deviating the response to tolerance. The physiological DC ability to induce Treg activation depends on various cytokines and costimulatory molecules, but the exact balance between these, particularly, in DCs from cancer patients, is still unclear. CD86 and CD80 bind to both stimulatory (CD28) and inhibitory (CTLA-4) receptors on $\mathrm{T}$ cells, with different affinities [93]. In human DCs, the induction and upregulation of CD86 was shown to influence significantly T-cell activation [94], while studies in knockout mice have indicated that DCs ability to generate/expand Treg subsets can be related to the balance of CD80 and CD86 $[89,95]$.

Confirming the significant role of CTLA-4 signaling in the immunosuppression of cancer patients, the blockage of this molecule in clinical settings by monoclonal antibodies has been able to improve significantly the survival of metastatic melanoma patients [96, 97]. Additionally, PD-L1, ICOS-L, and TGF-beta seem to emerge as good candidates for the in vitro manipulation of DC phenotype/function for immunotherapeutic approaches. More recently, clinical trials targeting the PD-1/PD-L1 axis with anti-PD1 monoclonal 

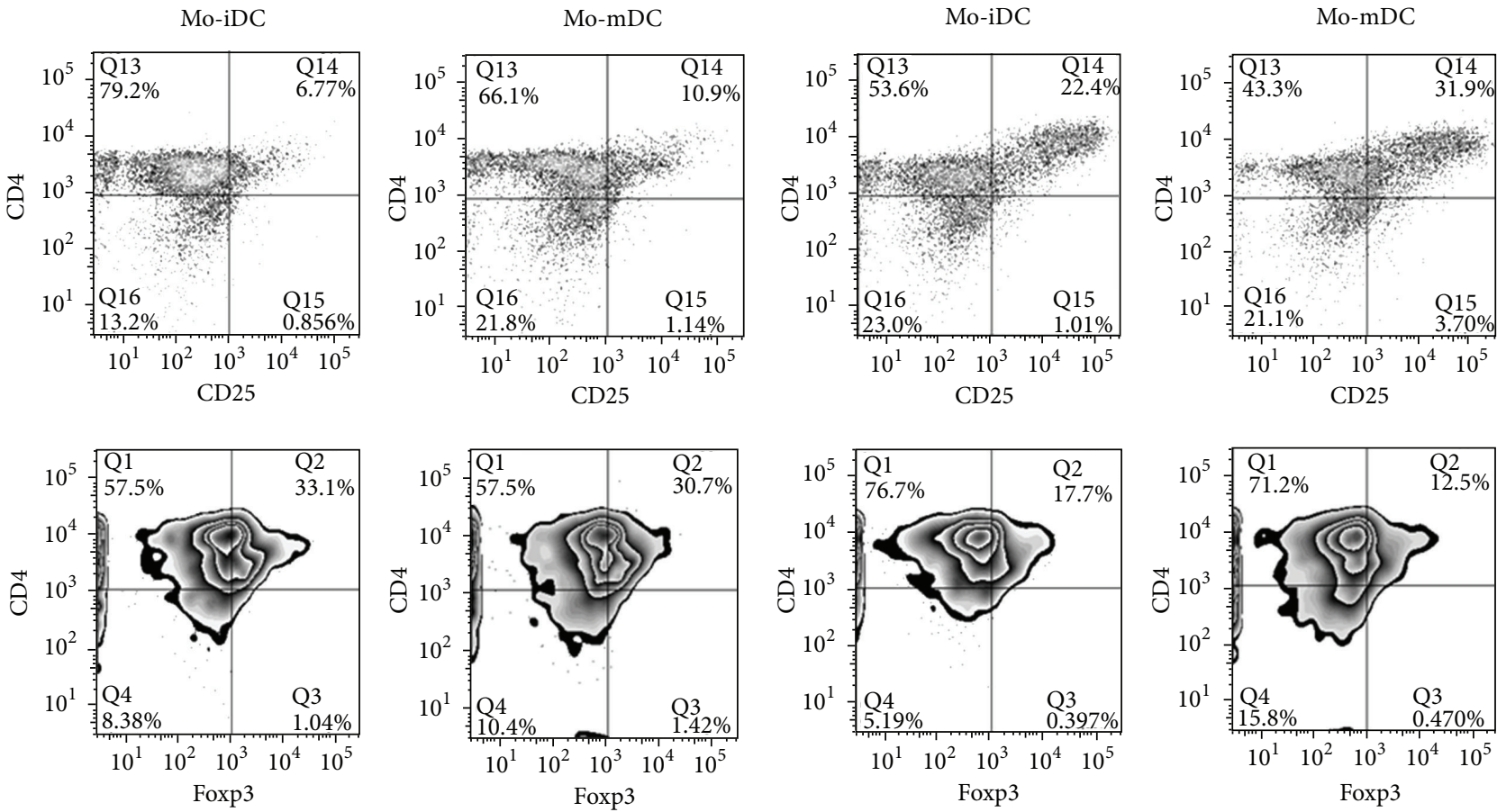

(a)

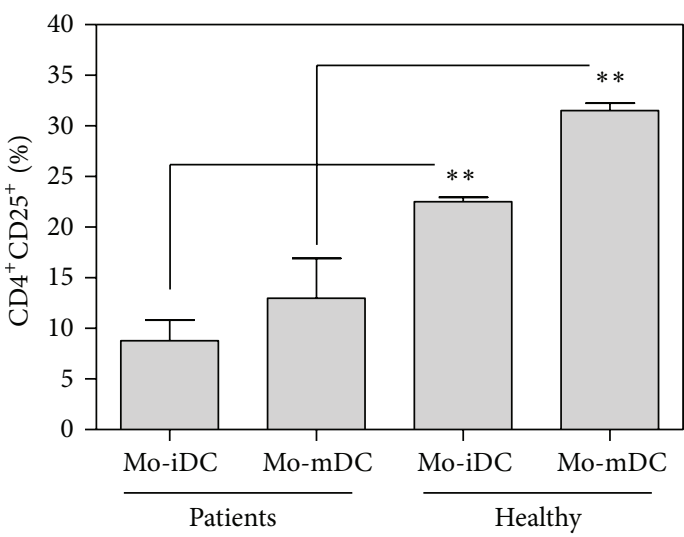

(b)

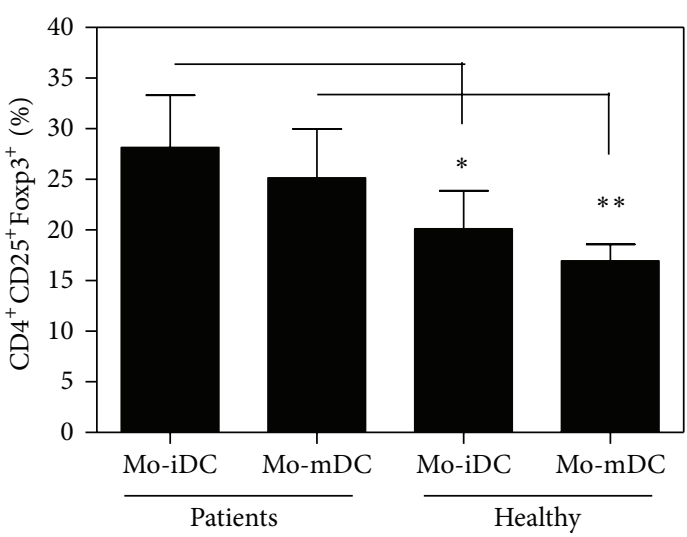

(c)

Figure 2: Patients' Mo-DCs fail to activate CD4 $4^{+}$lymphocytes and induce higher Foxp3 expression even after maturation. Mo-DCs from controls and breast cancer patients were cocultured with allogeneic $\mathrm{CD} 4^{+} \mathrm{CD} 45 \mathrm{RA}{ }^{+}$cells for five days. At the end of culture the phenotype of lymphocytes was evaluated by flow cytometry. (a) Representative experiments of CD25 and Foxp3 expression in CD $4^{+}$lymphocytes stimulated by immature DCs (Mo-iDCs) or mature DCs (Mo-mDCs) from healthy donors or breast cancer patients. Average frequency of $\mathrm{CD} 25^{+}$cells (b) and $\mathrm{CD}^{+} \mathrm{CD} 25^{+} \mathrm{Foxp}^{+}$cells (c) after $\mathrm{CD}^{+} \mathrm{CD} 45 \mathrm{RA}^{+}$lymphocytes' coculture with Mo-DCs $\left({ }^{*} \mathrm{P}<0.05 ;{ }^{* *} P<0.01\right.$, two-tailed unpaired $t$-test; $n=4$ ). (Mature Mo-DCs were activated by TNF-alfa for 48 hours.)

antibodies revealed their safety [98] and achieved promising results, with tumor regressions in patients with advanced cancer $[99,100]$, thus indicating another possible pathway to be explored in the clinic.

Nevertheless, these data are still sparse and much needs to be determined before an effective manipulation of DC phenotype and function is achieved. In order to accomplish this, however, studies addressing the intracellular signaling pathways in tumor-affected DCs are urgently needed and may shed light on the precise mechanisms of their response to tumors as well as provide molecular targets for their effective manipulation.

\section{Abbreviations}

APCs: Antigen-presenting cells

DCs: Dendritic cells

GM-CSF: Granulocyte macrophage colony stimulating factor 
Patients Mo-iDCs
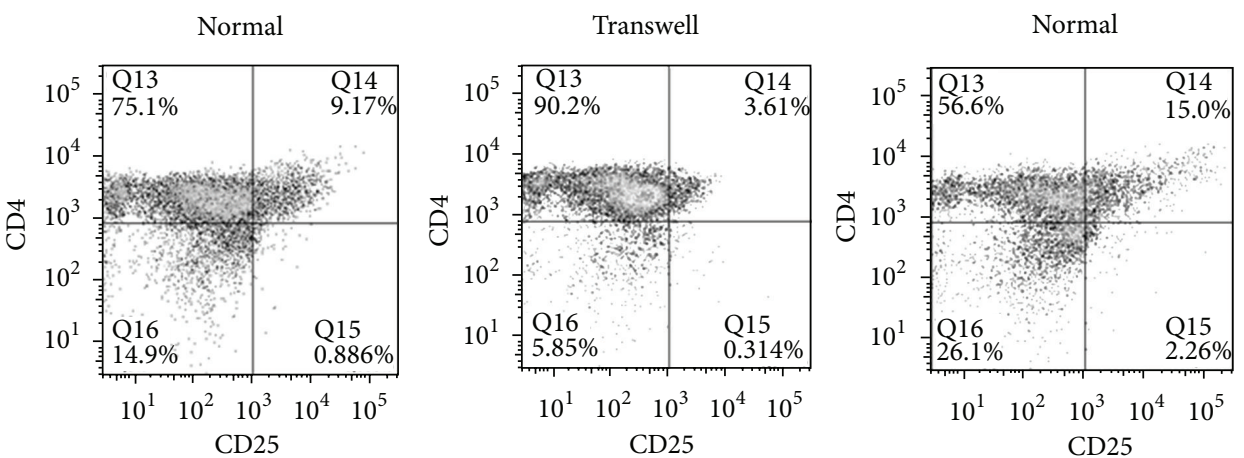

Patients Mo-mDCs
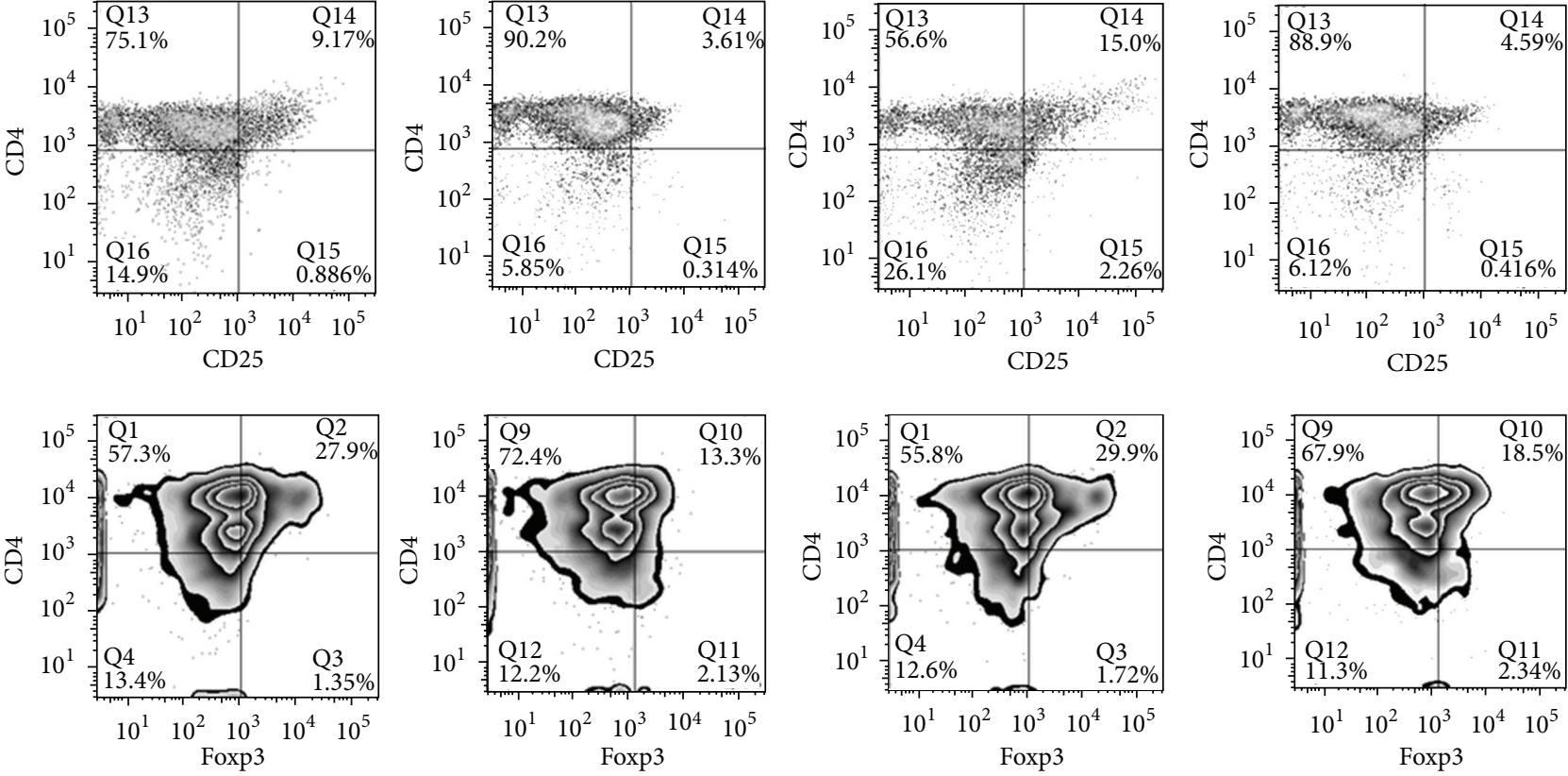

(a)

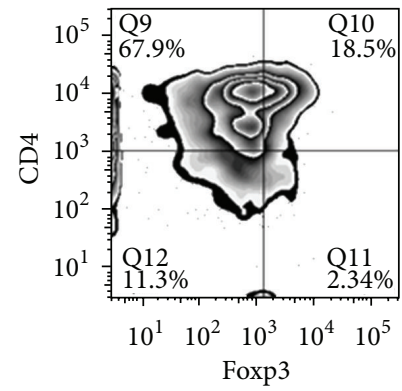

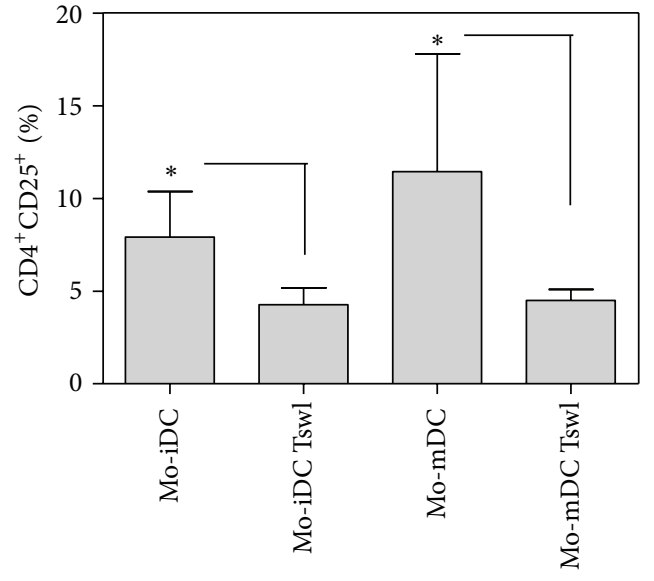

(b)

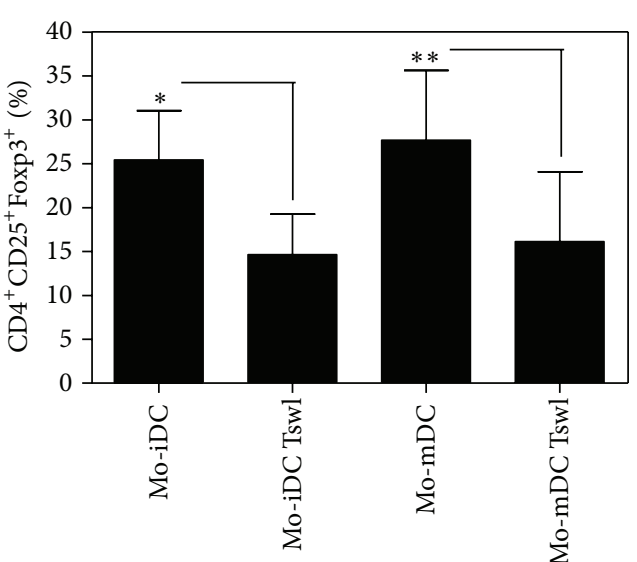

(c)

Figure 3: Patients' Mo-DCs induce expansion of regulatory T lymphocytes with the cooperation of contact molecules. Mo-DCs from breast cancer patients were cocultured with allogeneic $\mathrm{CD} 4{ }^{+} \mathrm{CD} 45 \mathrm{RA}^{+}$cells for five days in a transwell system or not. At the end of culture the phenotype of lymphocytes was evaluated by flow cytometry. (a) Representative experiments of CD25 and Foxp3 expression in CD4 ${ }^{+}$ lymphocytes stimulated by immature DCs (Mo-iDCs) or mature DCs (Mo-mDCs) from breast cancer patients in normal or transwell condition. Average frequency of CD $25^{+}$cells (b) and $\mathrm{CD}^{+} \mathrm{CD} 25^{+}$Foxp $3^{+}$cells (c) after $\mathrm{CD} 4^{+} \mathrm{CD} 45 \mathrm{RA}{ }^{+}$lymphocytes' coculture with patients' Mo-DCs $\left({ }^{*} P<0.05 ;{ }^{* *} P<0.01\right.$, paired $t$-test; $\left.n=4\right)$. (Tswl: transwell system; mature Mo-DCs were activated by TNF-alfa for 48 hours.)

IFN-gamma: Interferon-gamma

MFI: $\quad$ Median fluorescence intensity

MHC: $\quad$ Major histocompatibility complex

Mo-DCs: $\quad$ Monocyte-derived dendritic cells

Mo-iDCs: Monocyte-derived immature dendritic cells

Mo-mDCs: Monocyte-derived mature dendritic cells
PBMCs: Peripheral blood mononuclear cells

pDCs: $\quad$ Plasmacytoid dendritic cells

TGF-beta: Transforming growth factor-beta

TNF-alpha: Tumor necrosis factor-alpha

Tregs: Regulatory T cells

TSLP: $\quad$ Thymic stromal lymphopoietin

Tswl: Transwell coculture system. 


\section{Acknowledgments}

This study was supported by Grants (no. 2009/54599-5; no. 2011/08905-7) from the Fundação de Amparo a Pesquisa do Estado de São Paulo (FAPESP) and CNPq.

\section{References}

[1] S. Sakaguchi, M. Miyara, C. M. Costantino, and D. A. Hafler, "FOXP3 ${ }^{+}$regulatory $\mathrm{T}$ cells in the human immune system," Nature Reviews Immunology, vol. 10, no. 7, pp. 490-500, 2010.

[2] M. G. Roncarolo and M. Battaglia, "Regulatory T-cell immunotherapy for tolerance to self antigens and alloantigens in humans," Nature Reviews Immunology, vol. 7, no. 8, pp. 585-598, 2007.

[3] A. P. Campanelli, A. M. Roselino, K. A. Cavassani et al., " $\mathrm{CD} 4{ }^{+} \mathrm{CD} 25^{+} \mathrm{T}$ cells in skin lesions of patients with cutaneous leishmaniasis exhibit phenotypic and functional characteristics of natural regulatory T cells," Journal of Infectious Diseases, vol. 193, no. 9, pp. 1313-1322, 2006.

[4] T. J. Curiel, G. Coukos, L. Zou et al., "Specific recruitment of regulatory $\mathrm{T}$ cells in ovarian carcinoma fosters immune privilege and predicts reduced survival," Nature Medicine, vol. 10, no. 9, pp. 942-949, 2004.

[5] E. M. Shevach, " $\mathrm{CD} 4^{+} \mathrm{CD} 25^{+}$suppressor T cells: more questions than answers," Nature Reviews Immunology, vol. 2, no. 6, pp. 389-400, 2002.

[6] G. P. Dunn, L. J. Old, and R. D. Schreiber, "The immunobiology of cancer immunosurveillance and immunoediting," Immunity, vol. 21, no. 2, pp. 137-148, 2004.

[7] W. Zou, "Immunosuppressive networks in the tumour environment and their therapeutic relevance," Nature Reviews Cancer, vol. 5, no. 4, pp. 263-274, 2005.

[8] J. Banchereau and A. K. Palucka, "Dendritic cells as therapeutic vaccines against cancer," Nature Reviews Immunology, vol. 5, no. 4, pp. 296-306, 2005.

[9] W. Zou, "Regulatory $\mathrm{T}$ cells, tumour immunity and immunotherapy," Nature Reviews Immunology, vol. 6, no. 4, pp. 295-307, 2006.

[10] T. J. Curiel, "Tregs and rethinking cancer immunotherapy," Journal of Clinical Investigation, vol. 117, no. 5, pp. 1167-1174, 2007.

[11] U. K. Liyanage, T. T. Moore, H. G. Joo et al., "Prevalence of regulatory $\mathrm{T}$ cells is increased in peripheral blood and tumor microenvironment of patients with pancreas or breast adenocarcinoma," Journal of Immunology, vol. 169, no. 5, pp. 2756-2761, 2002.

[12] E. Y. Woo, C. S. Chu, T. J. Goletz et al., "Regulatory CD $4^{+} \mathrm{CD} 25^{+}$ $\mathrm{T}$ cells in tumors from patients with early-stage non-small cell lung cancer and late-stage ovarian cancer," Cancer Research, vol. 61, no. 12, pp. 4766-4772, 2001.

[13] R. N. Ramos, C. E. Oliveira, T. H. Gasparoto et al., "CD25+ $\mathrm{T}$ cell depletion impairs murine squamous cell carcinoma development via modulation of antitumor immune responses," Carcinogenesis, vol. 33, no. 4, pp. 902-909, 2012.

[14] H. Jonuleit, E. Schmitt, G. Schuler, J. Knop, and A. H. Enk, "Induction of interleukin 10-producing, nonproliferating $\mathrm{CD} 4^{+}$ $\mathrm{T}$ cells with regulatory properties by repetitive stimulation with allogeneic immature human dendritic cells," Journal of Experimental Medicine, vol. 192, no. 9, pp. 1213-1222, 2000.
[15] M. V. Dhodapkar and R. M. Steinman, "Antigen-bearing immature dendritic cells induce peptide-specific $\mathrm{CD} 8^{+}$regulatory T cells in vivo in humans," Blood, vol. 100, no. 1, pp. 174-177, 2002.

[16] Y. Belkaid and G. Oldenhove, "Tuning microenvironments: induction of regulatory T cells by dendritic cells," Immunity, vol. 29, no. 3, pp. 362-371, 2008.

[17] D. K. Banerjee, M. V. Dhodapkar, E. Matayeva, R. M. Steinman, and K. M. Dhodapkar, "Expansion of FOXP3high regulatory T cells by human dendritic cells (DCs) in vitro and after injection of cytokine-matured DCs in myeloma patients," Blood, vol. 108, no. 8, pp. 2655-2661, 2006.

[18] M. P. Colombo and S. Piconese, "Regulatory T-cell inhibition versus depletion: the right choice in cancer immunotherapy," Nature Reviews Cancer, vol. 7, no. 11, pp. 880-887, 2007.

[19] M. Gobert, I. Treilleux, N. Bendriss-Vermare et al., "Regulatory T cells recruited through CCL22/CCR4 are selectively activated in lymphoid infiltrates surrounding primary breast tumors and lead to an adverse clinical utcome," Cancer Research, vol. 69, no. 5, pp. 2000-2009, 2009.

[20] C. Bernabeu, J. M. Lopez-Novoa, and M. Quintanilla, "The emerging role of TGF- $\beta$ superfamily coreceptors in cancer," Biochimica et Biophysica Acta, vol. 1792, no. 10, pp. 954-973, 2009.

[21] B. Bierie and H. L. Moses, "Transforming growth factor beta (TGF- $\beta$ ) and inflammation in cancer," Cytokine and Growth Factor Reviews, vol. 21, no. 1, pp. 49-59, 2010.

[22] D. Gabrilovich, "Mechanisms and functional significance of tumour-induced dendritic-cell defects," Nature Reviews Immunology, vol. 4, no. 12, pp. 941-952, 2004.

[23] H. Ikushima and K. Miyazono, “TGFB 2 signalling: a complex web in cancer progression," Nature Reviews Cancer, vol. 10, no. 6, pp. 415-424, 2010.

[24] D. P. Kodack, E. Chung, H. Yamashita et al., "Combined targeting of HER2 and VEGFR2 for effective treatment of HER2-amplified breast cancer brain metastases," Proceedings of the National Academy of Sciences of the United States of America, vol. 109, no. 45, pp. 3119-3127, 2012.

[25] J. Faget, C. Biota, T. Bachelot et al., "Early detection of tumor cells by innate immune cells leads to $\mathrm{T}(\mathrm{reg})$ recruitment through CCL22 production by tumor cells," Cancer Research, vol. 71, no. 19, pp. 6143-6152, 2011.

[26] D. M. Kuang, Q. Zhao, C. Peng et al., "Activated monocytes in peritumoral stroma of hepatocellular carcinoma foster immune privilege and disease progression through PD-L1," Journal of Experimental Medicine, vol. 206, no. 6, pp. 1327-1337, 2009.

[27] D. M. Pardoll, "Immunology beats cancer: a blueprint for successful translation," Nature Immunology, vol. 13, no. 12, pp. 1129-1132, 2012.

[28] A. Bonertz, J. Weitz, D. H. K. Pietsch et al., "Antigen-specific Tregs control $\mathrm{T}$ cell responses against a limited repertoire of tumor antigens in patients with colorectal carcinoma," Journal of Clinical Investigation, vol. 119, no. 11, pp. 3311-3321, 2009.

[29] A. Mantovani, G. Germano, F. Marchesi, M. Locatelli, and S. K. Biswas, "Cancer-promoting tumor-associated macrophages: new vistas and open questions," European Journal of Immunology, vol. 41, no. 9, pp. 2522-2525, 2011.

[30] I. Treilleux, J. Y. Blay, N. Bendriss-Vermare et al., "Dendritic cell infiltration and prognosis of early stage breast cancer," Clinical Cancer Research, vol. 10, no. 22, pp. 7466-7474, 2004.

[31] R. B. Baleeiro, L. B. Anselmo, F. A. Soares et al., "High frequency of immature dendritic cells and altered in situ production 
of interleukin- 4 and tumor necrosis factor- $\alpha$ in lung cancer," Cancer Immunology, Immunotherapy, vol. 57, no. 9, pp. 13351345, 2008.

[32] G. F. Ma, Q. Miao, X. Q. Zeng et al., "Transforming growth factor- $\$ 1$ and $-\beta 2$ in gastric precancer and cancer and roles in tumor-cell interactions with peripheral blood mononuclear cells in vitro," PLoS ONE, vol. 8, no. 1, pp. 542-549, 2013.

[33] M. Łukaszewicz-Zając, B. Mroczko, M. Kozłowski, J. Nikliński, J. Laudański, and M. Szmitkowski, "Clinical significance of serum macrophage-colony stimulating factor (M-CSF) in esophageal cancer patients and its comparison with classical tumor markers," Clinical Chemistry and Laboratory Medicine, vol. 48, no. 10, pp. 1467-1473, 2010.

[34] G. Scambia, U. Testa, P. Benedetti Panici et al., "Prognostic significance of interleukin 6 serum levels in patients with ovarian cancer," British Journal of Cancer, vol. 71, no. 2, pp. 354356, 1995.

[35] M. Plante, S. C. Rubin, G. Y. Wong, M. G. Federici, C. L. Finstad, and G. A. Gastl, "Interleukin-6 level in serum and ascites as a prognostic factor in patients with epithelial ovarian cancer," Cancer, vol. 73, no. 7, pp. 1882-1888, 1994.

[36] D. I. Gabrilovich and S. Nagaraj, "Myeloid-derived suppressor cells as regulators of the immune system," Nature Reviews Immunology, vol. 9, no. 3, pp. 162-174, 2009.

[37] A. Pinzon-Charry, C. S. Ho, T. Maxwell et al., "Numerical and functional defects of blood dendritic cells in early- and latestage breast cancer," British Journal of Cancer, vol. 97, no. 9, pp. 1251-1259, 2007.

[38] B. Ruffell, A. Au, H. S. Rugo, L. J. Esserman, E. S. Hwang, and L. M. Coussens, "Leukocyte composition of human breast cancer," Proceedings of the National Academy of Sciences of the United States of America, vol. 109, no. 8, pp. 2796-2801, 2012.

[39] M. E. Dudley, J. R. Wunderlich, P. F. Robbins et al., "Cancer regression and autoimmunity in patients after clonal repopulation with antitumor lymphocytes," Science, vol. 298, no. 5594, pp. 850-854, 2002.

[40] C. Borg, I. Ray-Coquard, I. Philip et al., "CD4 lymphopenia as a risk factor for febrile neutropenia and early death after cytotoxic chemotherapy in adult patients with cancer," Cancer, vol. 101, no. 11, pp. 2675-2680, 2004.

[41] A. P. Rapoport, E. A. Stadtmauer, N. Aqui et al., "Restoration of immunity in lymphopenic individuals with cancer by vaccination and adoptive T-cell transfer," Nature Medicine, vol. 11, no. 11, pp. 1230-1237, 2005.

[42] J. Banchereau and R. M. Steinman, "Dendritic cells and the control of immunity, Nature, vol. 392, no. 6673, pp. 245-252, 1998.

[43] B. Pulendran, J. L. Smith, G. Caspary et al., "Distinct dendritic cell subsets differentially regulate the class of immune response in vivo," Proceedings of the National Academy of Sciences of the United States of America, vol. 96, no. 3, pp. 1036-1041, 1999.

[44] J. Banchereau, F. Briere, C. Caux et al., "Immunobiology of dendritic cells," Annual Review of Immunology, vol. 18, pp. 767811, 2000.

[45] M. K. Levings, S. Gregori, E. Tresoldi, S. Cazzaniga, C. Bonini, and M. G. Roncarolo, "Differentiation of Trl cells by immature dendritic cells requires IL-10 but not $\mathrm{CD} 25^{+} \mathrm{CD} 4^{+} \mathrm{Tr}$ cells," Blood, vol. 105, no. 3, pp. 1162-1169, 2005.

[46] S. L. Bailey, B. Schreiner, E. J. McMahon, and S. D. Miller, "CNS myeloid DCs presenting endogenous myelin peptides "preferentially" polarize CD4 ${ }^{+} \mathrm{TH}-17$ cells in relapsing EAE," Nature Immunology, vol. 8, no. 2, pp. 172-180, 2007.
[47] J. M. Ilarregui, D. O. Croci, G. A. Bianco et al., "Tolerogenic signals delivered by dendritic cells to $T$ cells through a galectin1-driven immunoregulatory circuit involving interleukin 27 and interleukin 10," Nature Immunology, vol. 10, no. 9, pp. 981-991, 2009.

[48] S. Della Bella, M. Gennaro, M. Vaccari et al., "Altered maturation of peripheral blood dendritic cells in patients with breast cancer," British Journal of Cancer, vol. 89, no. 8, pp. 1463-1472, 2003.

[49] A. R. Neves, L. F. C. Ensina, L. B. Anselmo et al., "Dendritic cells derived from metastatic cancer patients vaccinated with allogeneic dendritic cell-autologous tumor cell hybrids express more CD86 and induce higher levels of interferongamma in mixed lymphocyte reactions," Cancer Immunology, Immunotherapy, vol. 54, no. 1, pp. 61-66, 2005.

[50] V. Sisirak, J. Faget, M. Gobert et al., "Impaired IFN- $\alpha$ production by plasmacytoid dendritic cells favors regulatory T-cell expansion that may contribute to breast cancer progression," Cancer Research, vol. 72, pp. 5188-5197, 2012.

[51] S. I. Labidi-Galy, V. Sisirak, P. Meeus et al., "Quantitative and functional alterations of plasmacytoid dendritic cells contribute to immune tolerance in ovarian cancer," Cancer Research, vol. 71, no. 16, pp. 5423-5434, 2011.

[52] G. A. Rabinovich, D. Gabrilovich, and E. M. Sotomayor, "Immunosuppressive strategies that are mediated by tumor cells," Annual Review of Immunology, vol. 25, pp. 267-296, 2007.

[53] O. Fainaru, A. Adini, O. Benny et al., "Dendritic cells support angiogenesis and promote lesion growth in a murine model of endometriosis," FASEB Journal, vol. 22, no. 2, pp. 522-529, 2008.

[54] O. Fainaru, N. Almog, C. W. Yung et al., "Tumor growth and angiogenesis are dependent on the presence of immature dendritic cells," FASEB Journal, vol. 24, no. 5, pp. 1411-1418, 2010.

[55] A. Pedroza-Gonzalez, K. Xu, T. C. Wu et al., "Thymic stromal lymphopoietin fosters human breast tumor growth by promoting type 2 inflammation," Journal of Experimental Medicine, vol. 208, no. 3, pp. 479-490, 2011.

[56] F. Sallusto and A. Lanzavecchia, "Efficient presentation of soluble antigen by cultured human dendritic cells is maintained by granulocyte/macrophage colony-stimulating factor plus interleukin 4 and downregulated by tumor necrosis factor

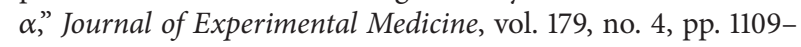
1118, 1994.

[57] F. J. Hsu, C. Benike, F. Fagnoni et al., "Vaccination of patients with B-cell lymphoma using autologous antigen-pulsed dendritic cells," Nature Medicine, vol. 2, no. 1, pp. 52-58, 1996.

[58] F. O. Nestle, S. Alijagic, M. Gilliet et al., "Vaccination of melanoma patients with peptide- or tumor lysate-pulsed dendritic cells," Nature Medicine, vol. 4, no. 3, pp. 328-332, 1998.

[59] J. A. M. Barbuto, L. F. C. Ensina, A. R. Neves et al., "Dendritic cell-tumor cell hybrid vaccination for metastatic cancer," Cancer Immunology, Immunotherapy, vol. 53, no. 12, pp. 1111-1118, 2004.

[60] Y. Andoh, N. Makino, and M. Yamakawa, "Dendritic cells fused with different pancreatic carcinoma cells induce different T-cell responses," OncoTargets and Therapy, vol. 6, pp. 29-40, 2013.

[61] P. Monti, B. E. Leone, A. Zerbi et al., “Tumor-derived MUC1 mucins interact with differentiating monocytes and induce IL10highIL-12low regulatory dendritic cell," Journal of Immunology, vol. 172, no. 12, pp. 7341-7349, 2004.

[62] I. E. Dumitriu, D. R. Dunbar, S. E. Howie, T. Sethi, and C. D. Gregory, "Human dendritic cells produce TGF- $\beta 1$ under the influence of lung carcinoma cells and prime the differentiation 
of $\mathrm{CD}^{+} \mathrm{CD} 25^{+}$Foxp $^{+}$regulatory T cells," Journal of Immunology, vol. 182, no. 5, pp. 2795-2807, 2009.

[63] F. Ghiringhelli, P. E. Puig, S. Roux et al., “Tumor cells convert immature myeloid dendritic cells into TGF- $\beta$-secreting cells inducing $\mathrm{CD}^{+} \mathrm{CD} 25^{+}$regulatory T cell proliferation," Journal of Experimental Medicine, vol. 202, no. 7, pp. 919-929, 2005.

[64] R. N. Ramos, L. S. Chin, A. P. Dos Santos, P. C. BergamiSantos, F. Laginha, and J. A. Barbuto, "Monocyte-derived dendritic cells from breast cancer patients are biased to induce $\mathrm{CD} 4^{+} \mathrm{CD} 25^{+}$Foxp $^{+}$regulatory $\mathrm{T}$ cells," Journal of Leukocyte Biology, vol. 92, pp. 673-682, 2012.

[65] T. L. Sumpter and A. W. Thomson, "The STATus of PD-L1 (B7H1) on tolerogenic APCs," European Journal of Immunology, vol. 41, no. 2, pp. 286-290, 2011.

[66] T. Yokosuka, M. Takamatsu, W. Kobayashi-Imanishi, A. Hashimoto-Tane, M. Azuma, and T. Saito, "Programmed cell death 1 forms negative costimulatory microclusters that directly inhibit $\mathrm{T}$ cell receptor signaling by recruiting phosphatase SHP2," The Journal of Experimental Medicine, vol. 209, pp. 12011217, 2012.

[67] S. Amarnath, C. M. Costanzo, J. Mariotti et al., "Regulatory T cells and human myeloid dendritic cells promote tolerance via programmed death ligand-1," PLoS Biology, vol. 8, no. 2, Article ID e1000302, 2010.

[68] N. Selenko-Gebauer, O. Majdic, A. Szekeres et al., "B7-H1 (programmed death-1 ligand) on dendritic cells is involved in the induction and maintenance of T cell anergy," Journal of Immunology, vol. 170, no. 7, pp. 3637-3644, 2003.

[69] C. Y. Mu, J. A. Huang, Y. Chen, C. Chen, and X. G. Zhang, "High expression of PD-L1 in lung cancer may contribute to poor prognosis and tumor cells immune escape through suppressing tumor infiltrating dendritic cells maturation," Medical Oncology, vol. 28, pp. 682-688, 2011.

[70] A. E. Morelli and A. W. Thomson, "Tolerogenic dendritic cells and the quest for transplant tolerance," Nature Reviews Immunology, vol. 7, no. 8, pp. 610-621, 2007.

[71] R. Kushwah, J. Wu, J. R. Oliver et al., "Uptake of apoptotic DC converts immature DC into tolerogenic DC that induce differentiation of Foxp $3^{+}$Treg," European Journal of Immunology, vol. 40, no. 4, pp. 1022-1035, 2010.

[72] T. B. Da Costa, L. R. Sardinha, R. Larocca, J. P. S. Peron, and L. V. Rizzo, "Allogeneic apoptotic thymocyte-stimulated dendritic cells expand functional regulatory T cells," Immunology, vol. 133, no. 1, pp. 123-132, 2011.

[73] K. Sato, N. Yamashita, M. Baba, and T. Matsuyama, "Modified myeloid dendritic cells act as regulatory dendritic cells to induce anergic and regulatory T cells," Blood, vol. 101, no. 9, pp. 35813589, 2003.

[74] H. Torres-Aguilar, S. R. Aguilar-Ruiz, G. González-Pérez et al., "Tolerogenic dendritic cells generated with different immunosuppressive cytokines induce antigen-specific anergy and regulatory properties in memory $\mathrm{CD}^{+}{ }^{\mathrm{T}}$ cells," The Journal of Immunology, vol. 184, pp. 1765-1775, 2010.

[75] X. Luo, K. V. Tarbell, H. Yang et al., "Dendritic cells with TGF$\beta 1$ differentiate naïve $\mathrm{CD} 4{ }^{+} \mathrm{CD} 25^{-} \mathrm{T}$ cells into islet-protective Foxp $3^{+}$regulatory T cells," Proceedings of the National Academy of Sciences of the United States of America, vol. 104, no. 8, pp. 2821-2826, 2007.

[76] G. Penna, A. Roncari, S. Amuchastegui et al., "Expression of the inhibitory receptor ILT3 on dendritic cells is dispensable for induction of $\mathrm{CD}^{+} \mathrm{Foxp}^{+}$regulatory $\mathrm{T}$ cells by 1,25dihydroxyvitamin D3," Blood, vol. 106, no. 10, pp. 3490-3497, 2005.

[77] W. W. J. Unger, S. Laban, F. S. Kleijwegt, A. R. Van Der Slik, and B. O. Roep, "Induction of Treg by monocyte-derived DC modulated by vitamin D3 or dexamethasone: differential role for PD-L1," European Journal of Immunology, vol. 39, no. 11, pp. 3147-3159, 2009.

[78] S. Rutella, S. Danese, and G. Leone, "Tolerogenic dendritic cells: cytokine modulation comes of age," Blood, vol. 108, no. 5, pp. 1435-1440, 2006.

[79] M. Menges, S. Rößner, C. Voigtländer et al., "Repetitive injections of dendritic cells matured with tumor necrosis factor $\alpha$ induce antigen-specific protection of mice from autoimmunity," Journal of Experimental Medicine, vol. 195, no. 1, pp. 15-21, 2002.

[80] V. Sisirak, N. Vey, N. Goutagny et al., "Breast cancer-derived TGF- $\beta$ and TNF- $\alpha$ compromise IFN- $\alpha$ production by tumorassociated plasmacytoid dendritic cells," International Journal of Cancer, 2013.

[81] C. J. M. Melief, "Cancer immunotherapy by dendritic cells," Immunity, vol. 29, no. 3, pp. 372-383, 2008.

[82] S. K. Watkins, Z. Zhu, E. Riboldi et al., "FOXO3 programs tumor-associated DCs to become tolerogenic in human and murine prostate cancer," The Journal of Clinical Investigation, no. 4, pp. 1361-1372, 2011.

[83] C. Conrad, J. Gregorio, Y. H. Wang et al., "Plasmacytoid dendritic cells promote immunosuppression in ovarian cancer via ICOS costimulation of Foxp $3^{+}$T-regulatory cells," Cancer Research, vol. 72, no. 20, pp. 5240-5249, 2012.

[84] J. Faget, N. Bendriss-Vermare, M. Gobert et al., "ICOS-ligand expression on plasmacytoid dendritic cells supports breast cancer progression by promoting the accumulation of immunosuppressive CD $4^{+}$T cells," Cancer Research, vol. 72, pp. 61306141, 2012.

[85] J. Massague, "How cells read TGF-beta signals," Nature Reviews Molecular Cell Biology, vol. 1, pp. 169-178, 2000.

[86] L. Gorelik, S. Constant, and R. A. Flavell, "Mechanism of transforming growth factor $\beta$-induced inhibition of $\mathrm{T}$ helper type 1 differentiation," Journal of Experimental Medicine, vol. 195, no. 11, pp. 1499-1505, 2002.

[87] R. K. Selvaraj and T. L. Geiger, "A kinetic and dynamic analysis of Foxp3 induced in T cells by TGF- $\beta$," Journal of Immunology, vol. 178, no. 12, pp. 7667-7677, 2007.

[88] M. Zeng, E. Guinet, and M. Nouri-Shirazi, "B7-1 and B7-2 differentially control peripheral homeostasis of $\mathrm{CD} 4^{+} \mathrm{CD} 25^{+} \mathrm{Foxp}^{+}$ regulatory T cells," Transplant Immunology, vol. 20, no. 3, pp. 171-179, 2009.

[89] Y. Zheng, C. N. Manzotti, M. Liu, F. Burke, K. I. Mead, and D. M. Sansom, "CD86 and CD80 differentially modulate the suppressive function of human regulatory T cells," Journal of Immunology, vol. 172, no. 5, pp. 2778-2784, 2004.

[90] L. Wang, K. Pino-Lagos, V. C. De Vries, I. Guleria, M. H. Sayegh, and R. J. Noelle, "Programmed death 1 ligand signaling regulates the generation of adaptive Foxp $3^{+} \mathrm{CD} 4^{+}$regulatory T cells," Proceedings of the National Academy of Sciences of the United States of America, vol. 105, no. 27, pp. 9331-9336, 2008.

[91] T. Fukaya, H. Takagi, Y. Sato et al., "Crucial roles of B7-H1 and B7-DC expressed on mesenteric lymph node dendritic cells in the generation of antigen-specific $\mathrm{CD} 4{ }^{+} \mathrm{Foxp}^{+}$regulatory $\mathrm{T}$ cells in the establishment of oral tolerance," Blood, vol. 116, no. 13, pp. 2266-2276, 2010. 
[92] K. Palucka and J. Banchereau, "Cancer immunotherapy via dendritic cells," Nature Reviews Cancer, vol. 12, pp. 265-277, 2012.

[93] A. H. Sharpe and G. J. Freeman, "The B7-CD28 superfamily," Nature Reviews Immunology, vol. 2, no. 2, pp. 116-126, 2002.

[94] D. M. Sansom, C. N. Manzotti, and Y. Zheng, "What's the difference between CD80 and CD86?" Trends in Immunology, vol. 24, no. 6, pp. 314-319, 2003.

[95] N. Perez, S. Karumuthil-Melethil, R. Li, B. S. Prabhakar, M. J. Holterman, and C. Vasu, "Preferential costimulation by CD 80 results in IL-10-dependent TGF- $\beta 1^{+}$-adaptive regulatory $\mathrm{T}$ cell generation," Journal of Immunology, vol. 180, no. 10, pp. 65666576, 2008

[96] F. S. Hodi, S. J. O’Day, D. F. McDermott et al., "Improved survival with ipilimumab in patients with metastatic melanoma," The New England Journal of Medicine, vol. 363, no. 8, pp. 711723, 2010.

[97] C. Robert, L. Thomas, I. Bondarenko et al., "Ipilimumab plus dacarbazine for previously untreated metastatic melanoma," The New England Journal of Medicine, vol. 364, no. 26, pp. 25172526, 2011.

[98] S. L. Topalian, F. S. Hodi, J. R. Brahmer et al., "Safety, activity, and immune correlates of anti-PD-1 antibody in cancer," The New England Journal of Medicine, vol. 366, no. 26, pp. 24432454, 2012.

[99] J. R. Brahmer, S. S. Tykodi, L. Q. Chow et al., "Safety and activity of anti-PD-L1 antibody in patients with advanced cancer," The New England Journal of Medicine, vol. 366, no. 26, pp. 24552465, 2012.

[100] E. J. Lipson, W. H. Sharfman, C. G. Drake et al., "Durable cancer regression off-treatment and effective reinduction therapy with an anti-PD-1 antibody," Clinical Cancer Research, vol. 19, no. 2, pp. $462-468,2013$. 


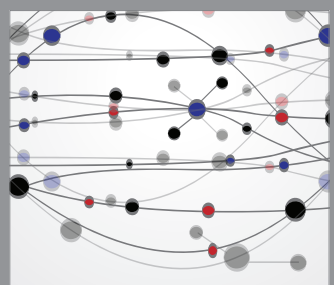

The Scientific World Journal
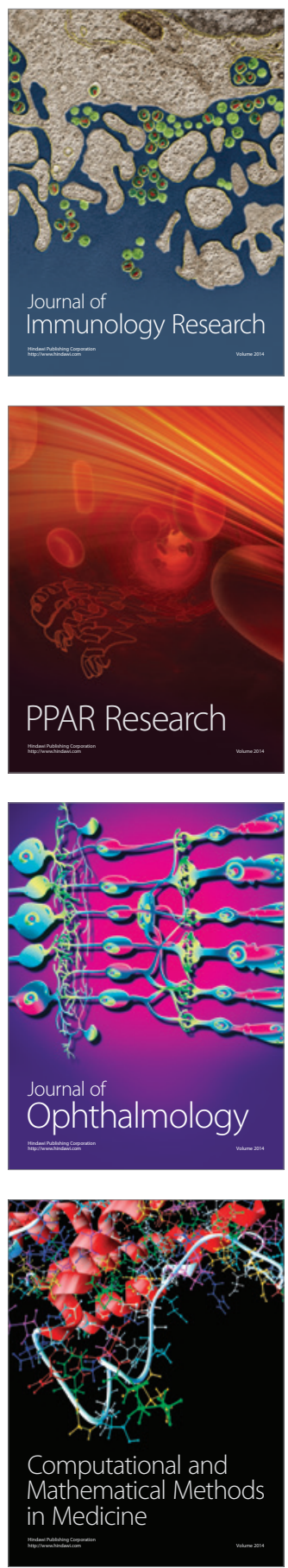

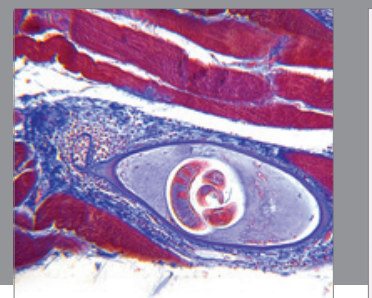

Gastroenterology

Research and Practice
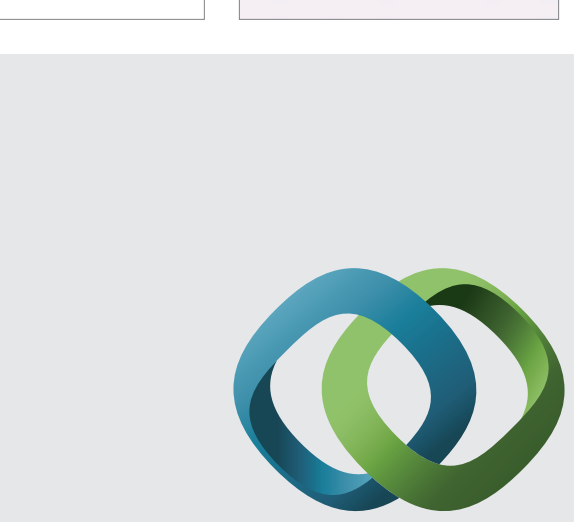

\section{Hindawi}

Submit your manuscripts at

http://www.hindawi.com
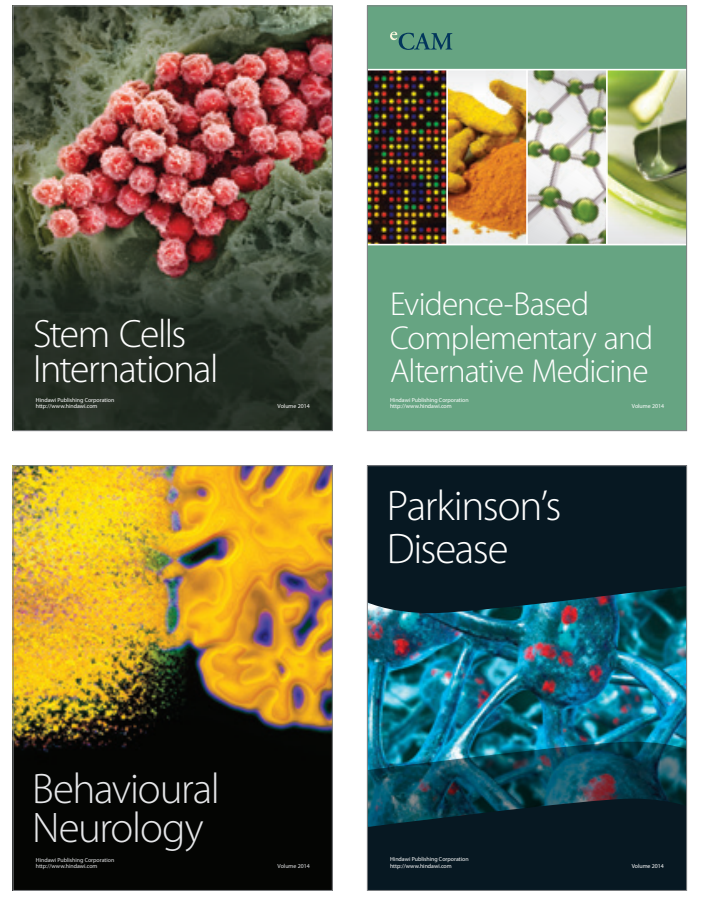
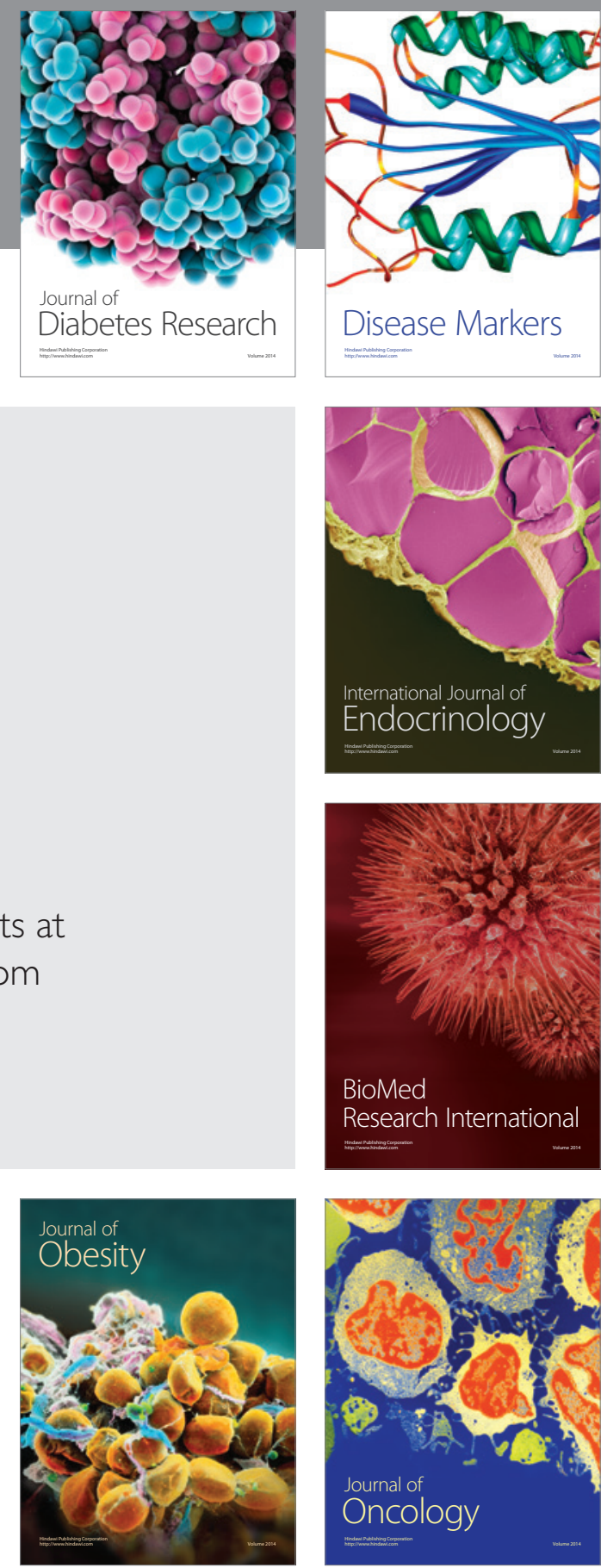

Disease Markers
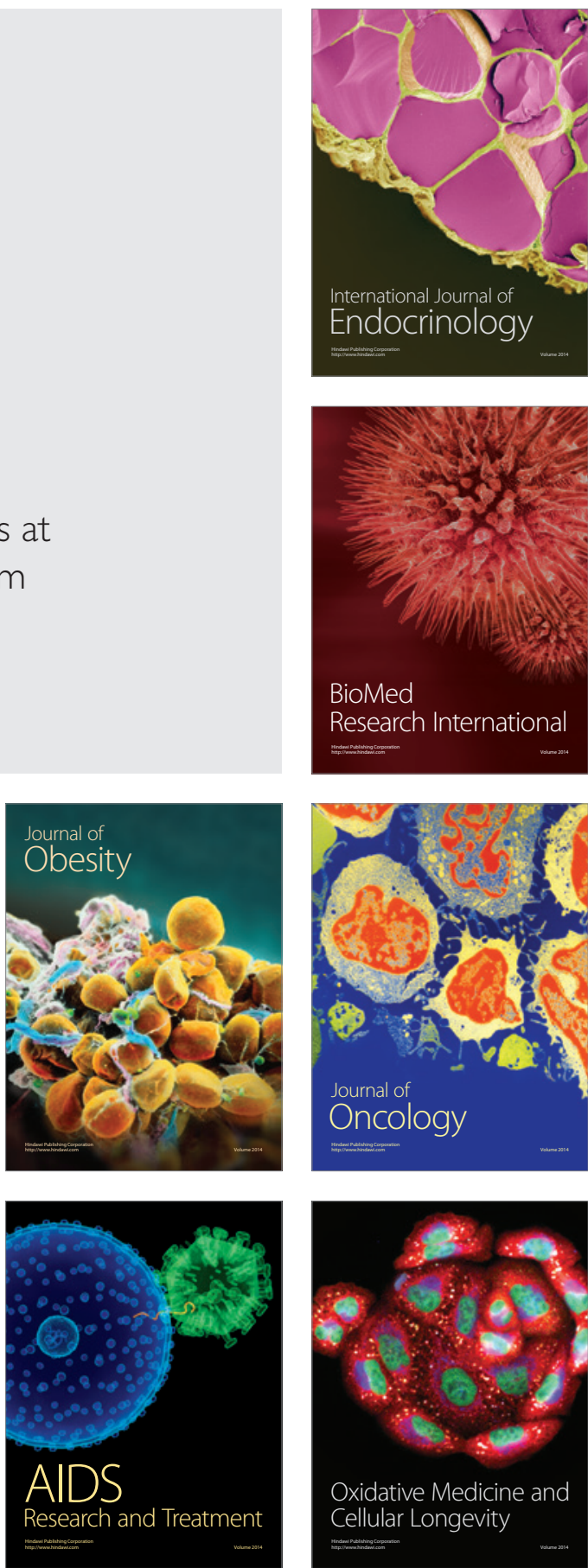